\title{
The Distribution and Population of Wreathed Hornbill (Aceros Udulatus) in Mount Ungaran Central Java
}

\author{
Margareta R. and Edi K. Nugroho
}

\begin{abstract}
Java Island has three species of Hornbills and one of the species is Aceros undulatus, located at Mount Ungaran Central Java. The mountain belongs to one of the Important Birds Areas (IBA) in Indonesia according to Birdlife International. The objective of this study was to find out the distribution and population of Aceros undulatus as an effort to support the urgency of bird conservation idea. The research stations are located in Medini, Mount Gentong, Gadjah Mungkur, and Banyuwindu areas. The study was conducted in April - October 2011. The bird observation method used was the VCP (Variable Circular Plot). The result shows that the distribution of bird are dominating in four observation stations of Mount Ungaran. The analysis of population shows that density value of Aceros undulatus was 14.60 individu/Km${ }^{2}$.
\end{abstract}

Index Terms-Aceros undulatus, distribution, population, Mount Ungaran.

\section{INTRODUCTION}

Mount Ungaran is one of the Important Birds Areas (IBA) in Indonesia, especially in Central Java. The Mountain is located in Kendal Regency and also Ungaran Regency with total areas around 5.500 hectares, and has a potential to be a natural forest on its uphill steep slopes [1].

According to Birdlife International [2], birds that belong to Bucerotidae family in Indonesia which are Wrinkled Hornbill (Aceros corrugatus), Black Hornbill (Antracoceros malayanus), Helmeted Hornbill (Rhinoplax vigil) are globally near-threatened, Sumba Hornbill (Aceros everetti) and Plainpouched Hornbill (Aceros subruficollis) are globally vulnerable and Whreathed Hornbill (Aceros undulatus) has been the least to concern. Based on CITES (Convention on International Trade of Endangered Species of Wild Fauna and Flora) [3], Hornbill belongs to the second appendix, which means it can only be traded only under specific circumstance, such as scientific research.

Three of Hornbills birds existing in Java [4], one of them, Aceros undulatus is found in Mount Ungaran. The citizen aoround of Mont Ungaran call "Gogik Bird" (local name). he The preliminary observations has been done in June to July 2009 and March to April 2010 to ensure the existence of Aceros undulatus in Mount Ungaran. Until now, the data about this bird's ecology, such as population, distribution,

Manuscript received April 4, 2013; revised June 5, 2013

R. Margareta is with Department of Biology, Semarang State University, Jl. Raya Sekaran Gunungpati Semarang Central Java 50229; Conservation Agency Semarang State University, Jl. Raya Sekaran Gunungpati Semarang Central Java (email: etak_sigid@yahoo.com).

Edi K. Nugroho is with Departement of Biology, Semarang State University, Jl. Raya Sekarang Gunungpati Semarang Central Java 50229 (email: Nug.edik@gmail.com). behavior, and habitat are still lacking. Therefore, it is urgent to do a research to find out the ecology and profile of Wreathed Hornbill in Mount Ungaran as one of the effort to preserve animals. Especially as there are serious threats for Hornbills such as habitat fragmentation, illegal logging, and birds trading in Mount Ungaran. Those threats will significantly endanger Hornbill's existence.

Hornbills tend to be affected by habitat disturbances including logging, forest fires and other habitat disturbance [5]-[7]. The awareness from society is not sufficient especially in the activities of protecting life buffering system and preserving the diversity of plants and animals along with its ecosystem [8]. Also, in the utilization activities, there is no effort to preserve the renewable resources and its ecosystem. This has a very close relation with education, knowledge, and the economical level of the society.

The objective of this study is to find out the ecology of Aceros undulatus in Mount Ungaran, especially the distribution and population of this species.

\section{PROCEDURE}

The Research Location was located in Mount Ungaran, Central Java, Indonesia. The Research Station spread in four locations; Medini, Mount Gentong, Gajah Mungkur and Banyuwindu. The research was conducted on April October 2011

The materials and equipments needed for this research were: binocular (Nikon 8 x 30, 8.3"CF WF), Monocular (Nikon 20 x 60), GPS (Global Positioning System) Garmyn e-trex 12 chanel, Bird Field Guide : Sumatra, Java, Bali, Kalimantan [9], thermometer, hygrometer, compass, camera, tape recorder, counter, stopwatch, tallysheet, roll meter, rope, and stationeries.

The Research starts at 6.00 am until $5.00 \mathrm{pm}$ and was taken by using the combination of line transec method and point count in the VCp (Variable Circular Plot).

\begin{tabular}{lcl}
\multicolumn{2}{c}{ TABEL I: DATA MEASUREMENT AND DATA ANALYSIS } \\
\hline Observed Variables & How to gather the data & Data Analysis \\
\hline $\begin{array}{l}\text { Species } \\
\text { identification }\end{array}$ & $\begin{array}{l}\text { line transec method } \\
\text { and VCp (Variable }\end{array}$ & Field Manual \\
Population & $\begin{array}{l}\text { Circular Plot }) \\
\text { Observation time: }\end{array}$ & $\begin{array}{l}\text { Population } \\
\text { Density (Buckland } \\
\text { et al. 1993) } \\
\text { Descriptive } \\
\text { Type of foods }\end{array}$ \\
$\begin{array}{ll}\text { Distribution } \\
\text { GPS ordinate spot }\end{array}$ & $\begin{array}{l}\text { Descriptive, } \\
\text { layout with } \\
\text { topography map }\end{array}$ \\
\hline
\end{tabular}

The formula used to measure the population is by using the population density [10] 


$$
D=\frac{n}{2 W L}
$$

$D=$ Population Density (birds $/ \mathrm{Km}^{2}$ )

$n=$ Total individual (bird)

$W=$ Path width $(\mathrm{Km})$

$L=$ Path length $(\mathrm{Km})$

\section{RESULT AND DISCUSSION}

The Observation of Wreathed Hornbill (Aceros undulates) population was conducted in four observation stations, they are; Medini, Gunung Gentong, Gadjah Mungkur, and Banyuwindu. These four locations have different type of habitat. Medini is surrounded by a large tea garden, next to the primary forest and the village, Gunung Gentong is the primary forest, Gadjah Mungkur is the border area between the primary forest and the tea garden, meanwhile Banyuwindu is a secondary forest.

The result of population density analysis [10] showed that Wreathed Hornbill's population density in five different stations are ranging from $11.59-22.80 \mathrm{birds} / \mathrm{Km}^{2}$ (Table II). The highest density is also found in Medini and the lowest is in Gunung Gentong. Generally, the population density in Mount is 14.60 birds $/ \mathrm{Km}^{2}$. This density is higher than in Nusakambangan Island which are 2 birds $/ \mathrm{Km}^{2}$ [11] and in the National Park, Bukit Barisan Lampung 7.5 birds/ $\mathrm{Km}^{2}[12]$.

TABLE II: The PopUlation Density of WreATHED HornBILLS IN

\begin{tabular}{ccc}
\multicolumn{3}{c}{ MounT UnGARAN } \\
\hline Station & Total Birds & Population Density $\left(\mathrm{birds} / \mathrm{Km}^{2}\right)$ \\
\hline Medini & 146 & 22.80 \\
Banyuwindu & 179 & 18.59 \\
Gadjah Mungkur & 117 & 14.90 \\
Gunung Gentong & 91 & 11,59 \\
\hline Total & 533 & 14.60 \\
\hline
\end{tabular}

The high quantity and tight population density in Medini Observation station is caused by some reasons, one of them is because this station is surrounded by an open-large tea garden and hills, as well as located next to the village. The open area makes it easy for the birds to be observed because the observation distance can be wider and clearer. Besides, Medini station is the routine flight-route of the Wreathed Hornbills from various directions, such as the move from Gunung Gentong area to the forest in Watu Ondo Forest, Gajah Mungkur, Banyuwindu and vice versa. In Medini, observer can also see clearly the activities of Wreathed Hornbills which are actively living around Watu Ondo area. The population density here is higher than in Banyuwindu forest, the area with steep slopes and high trees which has $18.59 \mathrm{birds} / \mathrm{km}^{2}$ of population density. Banyuwindu is a forest with a good condition to preserve Wreathed Hornbills because it has various types of big trees especially Ficus $s p$ which provides foods for Wreathed Hornbills. The topography in this area has $>30^{\circ}$ of slopes, and besides providing foods, the trees also provide shelters for Wreathed Hornbills.

The population density in Gadjah Mungkur is 14.90 birds $/ \mathrm{km}^{2}$. This station is the border between the tea garden and the primary forest. The forest in this area is still in a very good condition with the existence of taller and biger trees. Coffee plants are only planted at the valleys and do not belong to the forest area. This location is on a hill bordered by a river and tea garden.

The lowest population density is found in Gunung Gentong area with 11.59 birds $/ \mathrm{km}^{2}$. This is caused by the area of Gunung Gentong, even if its under the forest canopy, but it has already been planted by coffee plants, although it is still in a form of forest with big trees such as Ficus $s p$, cotton, Mesua ferea, Antidesma sp. Besides, Gunung Gentong is an area \pm 1500 above sea level consists of hills and slopes with $>30^{\circ}$ steep. This makes the observation distance is limited, other than that, it seems like Gunung Gentong is the shelter of Wreathed Hornbill so that it was hard to clearly see them as they were resting inside the shelters.

Wreathed Hornbills can be observed from those four station because of some factors, one of them is because Ficus $s p$ are found in those four areas and these trees are producing fruits which become the most favourite foods of Hornbills. Other than Ficus, there were also found some other trees which belong to the food of Wreathed Hornbills (Table III).

TABLE III: KINDS OF TREES WHICH BECOME FOOD SOURCES FOR WREATHED HORNBILLS

\begin{tabular}{|c|c|c|c|}
\hline No & Latin name & Local name & Family \\
\hline 1 & Ficus sp & Preh & Moraceae \\
\hline 2 & Bischoffia javanica & Gintungan & Euphorbiaceae \\
\hline 3 & Antidesma sp. & ande-ande lumut & Euphorbiaceae \\
\hline 4 & & uru Dimo & \\
\hline 5 & $\begin{array}{l}\text { Xanthophyllum } \\
\text { exoelsum }\end{array}$ & ndog-ndogan & Polygalaceae \\
\hline 6 & Terenna incerta & cangkok wesen & Rubiaceae \\
\hline 7 & Knema glauca & wuru karet & Myristicaceae \\
\hline 8 & & Bulu & \\
\hline 9 & Litsea sp & wuru Kembang & Lauraceae \\
\hline 10 & & wuru Kopi & Lauraceae \\
\hline 11 & Litsea angulata & wuru Kunir & Lauraceae \\
\hline 12 & & wuru kebo & Lauraceae \\
\hline 13 & Evodia glabra & trempayang & Rutaceae \\
\hline 14 & & Kemplang & \\
\hline 15 & $\begin{array}{l}\text { Eugenia } \\
\text { clavimyrtus }\end{array}$ & Salam watu & Myrtaceae \\
\hline
\end{tabular}

The loss of habitat is a serious threat for birds, including Wreathed Hornbills. Forest as the area where they live or as its habitat is an ecosystem in a form of place with natural resources which is dominated by trees and natural environment, are now mostly facing a critical threat. The illegal logging significantly contributes in destructing the trees like Ficus $s p$ and cotton which become the main objects of illegal logging. Ficus is a major food source for the hornbill [13], [14], as seen during the study of fruit and fruiting ficus whreathed hornbill perched on the tree for roosting and also eat the fruit of Ficus. Therefore, we need an organized preservation effort between government and society to be manifested through real action such as forestation.

It is estimated that the period between February-July and 
September-October are the reproduction period of Wreathed Hornbill [15], therefore during the observation on July-August some birds start appearing with their couple. The sex ratio of Wreathed Hornbill can be concluded from the sex ratio of Wreathed Hornbill during the observation, that is 1:1 (Table IV). This shows that the population of Wreathed Hornbill is not in the breading season, because if they are in the breading season, the number of males will be more than the females [16], because the female were in the nest cavities, and unite with the other Hornbills only during the nonbreeding period [17].

\begin{tabular}{cccc} 
TABLE IV: SEX RATIO WHREATHED HORNBILL ON MOUNT UNGARA \\
\cline { 2 - 4 } Station & Male & Female & Unidentified \\
\hline Medini & 45 & 55 & 44 \\
Banyuwindu & 66 & 69 & 44 \\
Gadjah Mungkur & 18 & 19 & 54 \\
Gunung Gentong & 44 & 46 & 27 \\
\hline Total & 173 & 189 & 171 \\
\hline Sex Ratio & \multicolumn{4}{c}{$1: 1$} \\
\hline
\end{tabular}

Some areas of Mount Ungaran are located in Kendal Regency and some are in Semarang Regency, approximately $21 \mathrm{~km}$ south from Semarang City. Mount Ungaran is covered by hills and valleys areas around 5.500 hectares, and has a potential natural forest on its uphill steep slopes. Meanwhile on the other part, there are tea garden, coffee and pine.

The result after observing the distribution and flight path shows that all four research locations are the habitat of Wreathed Hornbill, either as a place for perching, resting, eating, as well as reproducing. In every observation, there were found the birds which showed up with their partner. What was more interesting is that there were found three active nests in Mount Gantong. The high crising range of Wreathed Hornbill, approximately $50 \mathrm{~km}$ each day, makes it possible for them to explore the whole area searching for foods [18], [19]. All kinds of Hornbills like ripe fruits and collectively they search for the food sources. When the fruit season is over, collectively they will search for another area which fruits are riping, even if the habitat condition does not fit them [20], [21].

The kinds of trees that have been identified as the nest for Wreathed Hornbill on Mount Ungaran such as Photinia notonaniana, nagasari, and Cratoxylon sp. The activities seen during the research are the period when they build their nests. The finding of that location is then be used to determine the behavior of Wreathed Hornbill.

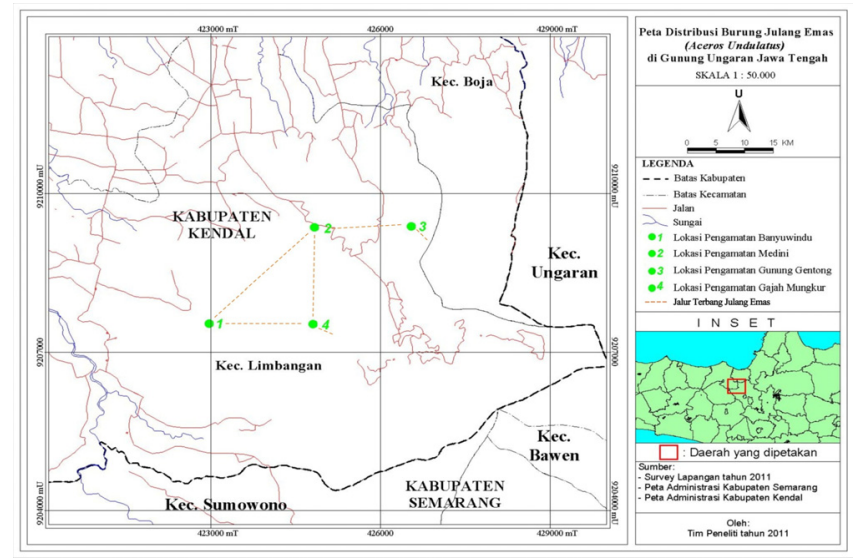

Fig 1. The flight route of Whreathed Hornbill in Mount Ungaran
The observation result of flight path shows the flight pattern of Whreathed Hornbill which is done in a routine schedule and pattern at all four observation locations (Medini, Mount Gentong, Banyuwindu, and Gadjahmungkur ) (Fig. $1)$.

The routine patern flight is Banyuwindu $\longleftrightarrow$ Medini ; Medini $\leftrightarrow$ Mount Gentong; Banyuwindu $\Rightarrow$ Medini $\Rightarrow$ Mount Gentong; Mount Gentong $\Rightarrow$ Medini $\Rightarrow$ Banyuwindu; Banyuwindu $\leftrightarrow$ Gajah Mungkur; Banyuwindu $\Rightarrow$ Gadjah Mungkur $\Rightarrow$ Medini; Medini $\Rightarrow$ Gajah Mungkur $\Rightarrow$ Banyuwindu.

\section{CONCLUSION}

Based on the research results, it can be concluded that Mount Ungaran is a suitable habitat for Wreathed Hornbill, either as a place to eat, take a rest, play, and breed. The research shows that The population density of Wreathed Hornbill in Mount Ungaran is between $11.59-22.80$ birds $/ \mathrm{Km}^{2}$. The highest density is found in Medini and the lowest is in Gunung Gentong. The population density in Mount Ungaran is 14.6 individual $/ \mathrm{Km}^{2}$. Generally the distribution of Wreathed Hornbill in Mount Ungaran spreading equally in four observation locations as Medini, Mount Gentong, Gadjahmungkur, and Banyuwindu.

\section{ACKNOWLEDGMENT}

The authors would like to thank to the Directorate General of Higher Education and Culture for funding the research. The expression of thanks are also addressed to the Association of Natural Conservation for giving the research license, to Pak Min and Pak Bekel who always become the helpful guide for the researcher. Misbahul Munir for taking a beautiful pictures and especially to the members of Green Community (Yuliani and friends) and Pelatuk Bird Study Club for giving their hands during the research.

\section{REFERENCES}

[1] R. Rudyanto, "Important bird area in Java and Bali," PKA/Birdlife International-Indonesia Programme, Bogor, pp. 77, 1999.

[2] Birdlife Internationale (June 2013). Conserving the worlds Birds. [On line]. Available: http://www.birdlife.org/datazone/ species search results.php?

[3] T. Soehartono and M. Ani, Implementation Cites Convention in Indonesi, Jakarta: Japan International Cooperation Agency (JICA), pp.345, 2003.

[4] W. Sukmantoro., M. Irham, W. Novarino, F. Hasudungan, N. Kemp, and M. Muchtar, Daftar Burung Indonesia no. 2, Indonesian Ornithologists' Union, Bogor, pp. 733, 2007.

[5] A. Johns, "Ecological effects of selective logging in a West Malaysian rain forests," PhD dissertation, Cambridge University, 1983

[6] A. D. Johns, "The use of primary and selectively logged rainforest by Malaysian Hornbills (Bucerotidae) and implications for their conservation," Biol. Conservation., vol. 40, Issue 3, pp. 179-190, 1987.

[7] H. H. de Iongh and M. van Weerd, "The use of avian guild for the monitoring of tropical forest disturbance by logging," Tropenbos International Wageningen, the Netherlands, pp. 16, 2006.

[8] W. Sukmantoro, "Hutan dan masyarakat," Majalah Kehutanan Indonesia, pp. 39-44, 2002.

[9] MacKinnon, J. Philips, S. Karen, and B. van Balen, "Bird in Sumatera, Jawa, Bali dan Kalimantan (Include Sabah, Serawak, dan Brunei Darussalam)," Jakarta: Puslitbang - Biologi, pp. 234, 2010.

[10] S. T. Bucland, D. R. Anderson, K. P. Burnham, and J. L. Laake (1996). Distance Sampling Estimating Abundance of Biological Populations. [Online] Available: http://www.colostate.edu /Dept/coopunit/ download.html 
[11] H. Nugroho, "Ecology of whreathed hornbill on the non breeding season in Nusakambangan Central Java," Indonesian Scientific Journal, vol. 9 (special edition), pp. 70-71, 2006.

[12] K. Anggraini, M. Kinnaird, and T. O.' Brien, "The effect of fruit availibility and habitat disturbance on an assemblage of sumatran hornbill," Bird Conservation International, vol. 10, pp. 189-202, September 2000.

[13] M. Shanahan, S. Samson, S. G. Compton, and R. Corlett, "Fig-eating by vertebrate frugivores: a globalreview," Biol. Rev., vol. 76, pp. 529-572, November 2001.

[14] F. R. Affandi and Winarni, "Preferensi dan interaction of hornbill and availibility ara fruit (Ficus spp) in Way Canguk, National Park of Bukit Barisan Lampung," in Proc. 2005. Seminar Ornithologi Indonesia, pp. 84-90, 2005.

[15] W. Marthy, "A review: Breeding ecology and nest site characteristics of Hornbills insitu and ex-situ," Harapan Rainforest, pp 12-13, 2008.

[16] H. Nugroho, "Ecology of Julang Emas on non breading season in Nusakambangan Central Java," Indonesian Scientific Journal, vol. 9 , (special edition), pp. 71-72, 2006.

[17] M. F. Kinnaird, T. O' Brien, and S. Suryadi, "Population fluctuation in Sulawesi Red-Knobbed Hornbills: Tracking figs in space and time," The Auk, vol. 113, no. 2, pp. 431-440, April 1996.

[18] M. F. Kinnaird and T. O' Brien, "Ecological effects of wild fire on lowland rainforest in Sumatra," Conserv. Biol., vol. 12, pp. 954-956, October 1998
[19] A. F. Sitompul, M. F. Kinnaird, and T. O' Brien, "Size matters: The effects of forest fragmentation and resource availability the endemic Sumba island Hornbill," Bird Conservation International, vol. 14, pp. S23-S37, December, 2004.

[20] M. F. Kinnaird and T. O.' Brien, "Ecological effects of wild fire on lowland rainforest in Sumatra," Conserv. Biol, vol. 12, pp. 954-956, Oktober 1998.

[21] A. Datta and G. S. Rawat, "Nest-site selection and nesting success of three hornbill species in Arunachal Pradesh, north-east India: Great Hornbill Bucerosbicornis, Wreathed Hornbill Aceros undulatus and Oriental Pied Hornbill Anthracoceros albirostris," Bird Conservation International, vol. 1, pp. S39-S52, December 2004.

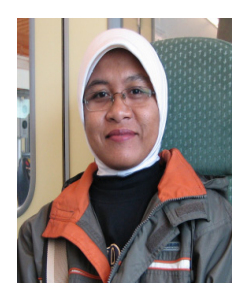

Margareta Rahayuningsih was born in Semarang Central Java Indonesia: 22 January 1970. She received Ph.D in Department of Natural Resources Conservation and Ecoturism-Forest Faculty, Bogor Agriculture Institute. She was a lecture in Department of Biology-Mathematic and Natural Science Faculty, Semarang State University. She also Head of Conservation Agency Semarang StateUniversity from 2011 until now. His expertise is in Animal Conservation, Biodiversity Conservation, Wildlife Ecology. 